\title{
The Evaluation of Urban Regeneration Processes
}

\author{
Leopoldo Sdino, Paolo Rosasco and Gianpiero Lombardini
}

\begin{abstract}
The conditions why processes of urban regeneration can be developed in modern-day cities have changed enormously over the last decade. Unlike the recent past, where the reuse for urban uses of former industrial areas was only based on maximising the amount of space, after the housing bubble begun in 2008, the profit margins for operators were reduced, and today, they faced to a sharp contraction in demand and a surplus of supply. Consequently, the framework within which we carry out the investment decisions is increasingly complex and is characterised by the opposition of a potential conflict between two forces. On the one hand, the public administration which seeks to take full advantage of the urban transformation processes to improve the quality of live for citizens; on the other, the private entity that has the aim of maximising the profits obtainable from the intervention and to the minimise business risk. Therefore, to ensure the overall feasibility of an intervention, urban viability must correspond to an economic and financial sustainability. The paper analyses the role of the economic evaluation in urban regeneration interventions through the analysis of a case study in the city of Genoa.
\end{abstract}

Keywords Urban regeneration - Economic and financial feasibility • Cost-Revenue analysis

\section{Introduction}

The conditions why processes of urban regeneration can be initiated in modern-day cities have changed radically over the last two decades, especially after the 20072010 crisis (Nespolo 2012; Cutini and Rusci 2016). While until the end of the last century the economic growth dynamics, although progressively weaker and unstable,

\section{Sdino $(\bowtie)$}

Architecture, Built Environment and Construction Engineering-ABC Department, Politecnico di Milano, Milan, Italy

e-mail: leopoldo.sdino@polimi.it

P. Rosasco · G. Lombardini

Department of Architectural and Design-DAD, University of Genoa, Genoa, Italy

(C) The Author(s) 2020

S. Della Torre et al. (eds.), Regeneration of the Built Environment from a Circular Economy Perspective, Research for Development, https://doi.org/10.1007/978-3-030-33256-3_6 
allowed interventions on the existing urban area that could be based on significant increases in real estate value, the economic conditions after the early 2000 s changed, reducing the economic profit for private investors. This was caused by the crisis in the real estate markets, mainly caused by excess of supply (De Gaspari 2013), repeated crises, economic stagnation and the state's fiscal crisis which has led to a drastic reduction in public and private investment.

So if initially, the urban transformation projects could be self-sustaining financially through the implementation of the changes of intended uses and the exploitation of agglomeration economies determined by the "positional income", with the passing of time and the change of economic conditions, these possibilities gradually are failed.

In this context, only big cities included in the large circuits of the flow economies and high finance are really attractive to financial capitals (Sassen 2001, 2018; Dicken 2003). In addition, the reduction in public investment makes local contexts increasingly dependent on private and international capital.

The location preferences for these "seeking value" capitals are extremely selective, as well as time-varying. The medium-sized cities have been pushed to the edges of the major processes and urban renewal projects. The strategies adopted by them are based on becoming as attractive as possible on the international markets of urban transformation (Ombuen 2018).

The transformation and urban redevelopment projects move within a framework characterised by actors who have, at least potentially, objectives and requirements that are opposed to one another:

- Public Administration, pursuing the maximum competitive advantage from the new regional planning and the improvement of environmental quality and the lives of citizens (Palermo and Ponzini 2012);

- Private Investors, which through real estate investing seek the maximisation of profits (Brenner and Theodore 2002).

The mission of the governance of urban transformation in this context therefore resides in the development of strategies to bring together other resources, more and more often by private investors, from which is possible obtain economics resources for creating infrastructure and services for the community.

\section{From the "Blueprint" Project to "Levante Waterfront" in Genoa}

The "Levante Waterfront" project is one of the most significant operations that lie ahead for the city of Genoa. It was conceived in the early twenty-first century to restore the sea area overlooking the city along the coastal stretch from Porto Antico (designed by Renzo Piano for the 1992 Expo) to the Corso Italia promenade.

Currently, the whole area is taken up by different functions (exhibition, production and port) and is in fact separated from the rest of the city. 


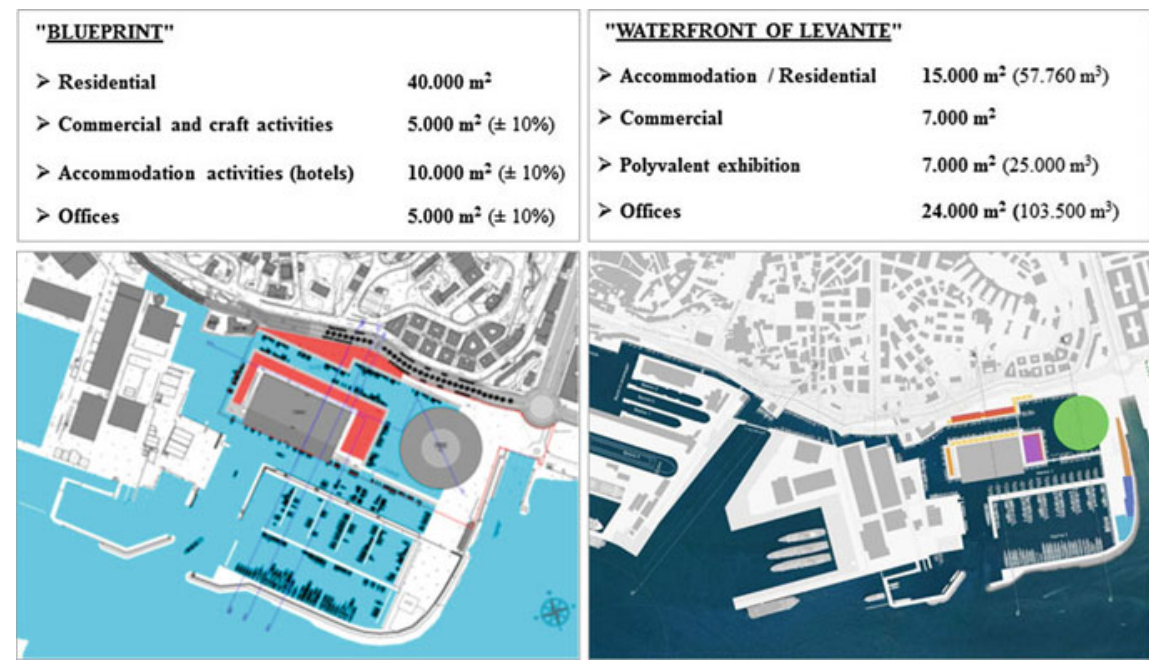

Fig. 1 Areas affected by the redevelopment project and square metres

The redevelopment projects began with the acquisition of areas and buildings of the exhibition site by the Municipality of Genoa in 2000 (for a value of 18.6 million euros). After a long period of pilot projects (among which the most important is the "Affresco" project developed in 2014 by Renzo Piano that redesigns the entire Genoese coastal strip), the urban transformation operation entered into an operational phase in 2014. In that year, Renzo Piano developed a first master plan for the coastal strip to the east of the city called the "Blueprint".

The transformation, conceived in this first phase, involved the construction of a new waterway (navigable channel) near the ancient city walls obtained by excavating existing pier sections and demolishing some disused buildings such as the ex-Nira building as well as some of the exhibition centre's obsolete.

The pedestrian walkway was placed along this dock, which should have been the missing link between Porto Antico and the Corso Italia promenade (in the eastern part of the exhibition area).

The total surface area for the new intended uses is equal to 48, $300 \mathrm{sqm}$.

With regards to the general design, the scope appearing to be the most complex among those identified was the one in the (ex) exhibition area: in accordance with the provisions of the urban plan of Genoa, the volumes of the demolished buildings use can be reconstructed in this area.

In 2016, the Municipality of Genoa established that the implementation of the "BluePrint" project (Fig. 1-left) should take place by means of a design competition developed in the areas owned by the municipality and SPIM. (the company

\footnotetext{
${ }^{1}$ Society for the Promotion of Heritage Property in the City of Genoa.
} 
designated as a guidance subject for the transformation). In July 2016, a competition notice was then issued which saw the participation of over 70 national and international groups of design.

The work of the appointed Selection Committee led to the conclusion of the procedure with no winner. Following the outcome of this competition and from the evolving urban dynamics of the city, a new project proposal has therefore been reached, the result of a reworking of the assembly design again by Renzo Piano, now called the "Levante Waterfront".

The changes to the "Blueprint" have maintained the idea of bringing the water near to the city but decreasing the building dimensions (Fig. 1-right).

The Municipality of Genoa has decided to proceed with the assessment by selling the entire compendium by evaluating the proposal in two different stages: in a first stage, the best compliance with the design idea of the "Levante Waterfront"; in a second phase, the technical and economic proposal (the latter regarding the tender for purchasing the areas). ${ }^{2}$

Within the pre-qualification questionnaire, it is confirmed that the Private Investor will take charge of the demolition of the former trade fair pavilions and the construction of the waterway ${ }^{3}$ (excluding the first part—at the west—which will be built by the municipality after the demolition of the ex-Nira ${ }^{4}$ building).

Between August and September 2018, the commission assessed the six proposals received, regarding only one as being eligible for the second phase (the most specifically designed and financial), the one from the Company EM2C from Lyon (France).

The French company, based on the economic elaborate checks, then notified about withdrawing the proposal in February 2019, considering the canal's construction cost as not being financially viable, which was required by the Municipality of Genoa. ${ }^{5}$

\section{The Economic Sustainability of the "Levante Waterfront"}

The feasibility of the project on the former Genoa exhibition area is therefore based not only on the urban and architectural plan but also on economical and financial

\footnotetext{
${ }^{2}$ Evaluated according to the most economically advantageous offer with the best value for money. As indicated in the tender documents, the price will fluctuate between 20 and 25 million euros (approximate values and not binding).

${ }^{3}$ The notice establishes a channel width of $40 \mathrm{~m}$ and a depth of $3.5 \mathrm{~m}$.

${ }^{4}$ The public funds used are from the "Pact for Genoa", signed in November 2016 between the national government and the Municipality of Genoa, which provides for a budget of 110 million euros for direct investment to be made in the city of Genoa. Specifically, for the Waterfront project, 13.5 million euros have been allocated in addition to the 15 million euros that were previously allocated.

${ }^{5}$ From the newspaper "Il Secolo XIX" (6 and 8 March 2019), the cost estimated by EM2C is about 70 million euros.
} 
Table 1 Intervention costs and contact persons

\begin{tabular}{l|l}
\hline Municipality of Genoa & Private investor \\
\hline Demolition of the former Nira building & Acquisition areas \\
\hline Waterway construction & Waterway completion \\
\hline \multirow{2}{*}{ Elevated stretch substitution $(500 \mathrm{~m})$} & Reuse of the S Pavilion (sports hall) \\
\cline { 2 - 2 } & $\begin{array}{l}\text { Creation of new buildings, facilities and docks for } \\
\text { mooring boats (53,000 sqm of SA) }\end{array}$ \\
\cline { 2 - 2 } & Public pedestrian footpaths and areas \\
\cline { 2 - 2 } & Parking for residents, businesses, moorings \\
\cline { 2 - 2 } & Urbanisation works (public car parks, etc.) \\
\hline \multirow{2}{*}{ Total cost: 50 million euros } & \\
\hline
\end{tabular}

sustainability; it must ensure the Private Investor who will develop the intervention an adequate profit margin for the capital invested.

In order to verify what the economic and financial viability conditions of the "Levante Waterfront" project are, a Cost-Revenue Analysis model (CRA) is developed, assuming the quantities of intended uses indicated by the Municipality of Genoa for various intended uses (residential, tertiary, etc.) (Fig. 1-right).

According to the instructions given in the tender documents and in the attached documents, costs were attributed to the two main parties according to Table 1.

According to the CRA, the evaluation of economic and financial sustainability is developed on the basis of two indicators (Prizzon 1995; Sdino et al. 2016):

- Net Present Value (NPV), which is the difference between revenues and discounted costs compared to the time of the assessment and estimated within the intervention/investment time period (55 years);

- Internal Rate of Return (IRR), which is the average percentage of the investment profitability referring to the time base assumed for the analysis of costs and revenues (one year, two months, etc.).

\section{The Evaluation of Costs and Revenues}

To estimate the construction costs for the buildings with different intended uses, a synthetic methodology ${ }^{6}$ is adopted while for the connecting channel with the Expo area of Genoa, a summarised bill of quantities is developed. Apart from the design

\footnotetext{
${ }^{6}$ The costs have been estimated on the basis of unit values taken from the price list for building typologies of the DEI for similar types and interventions.
} 
Table 2 Estimated construction costs

\begin{tabular}{l|r|r}
\hline \multirow{2}{*}{ Intended use } & \multicolumn{2}{l}{ Cost } \\
\cline { 2 - 3 } & \multicolumn{1}{l}{ Min. } & \multicolumn{1}{l}{ Max. } \\
\hline Purchase areas (€) & $25,000,000$ & $30,000,000$ \\
\hline Residential (€/sqm) & 1100 & 1800 \\
\hline Commercial (€/sqm) & 900 & 1700 \\
\hline Offices (€/sqm) & 1025 & 1500 \\
\hline Hospitality (€/room) & 70,000 & 85,000 \\
\hline Outdoor areas (€/sqm) & 70 & 140 \\
\hline $\begin{array}{l}\text { Underground car parks }(€ / \text { car } \\
\text { park) }\end{array}$ & 15,000 & 18,000 \\
\hline Waterway (€) & & $67,500,000$ \\
\hline Jetty dock $(€)$ & & $10,000,000$ \\
\hline Planning fees $(€)$ & & $20,000,000$ \\
\hline
\end{tabular}

$\operatorname{costs}^{7}$ and marketing costs, ${ }^{8}$ the general overheads of the Private Investor ${ }^{9}$ as well as the unexpected expenses ${ }^{10}$ are considered.

The assumed unitary costs are shown in Table 2.

Regard to the cost of the areas-which is the subject of the economic offer to be presented in the second phase-is considered equal to the average value among those indicated by the Municipality of Genoa. ${ }^{11}$

In the economic evaluation of a real estate development project, the forecast of the constructed real estate market values is one of the most critical factors that influence the value of sustainability indicators (Calabrò and Della Spina 2014; Napoli 2015; Rebaudengo and Prizzon 2017).

For the estimation of unit market values for the residential properties, an analysis of some property realities was developed which have some similarities to the one in question in terms of their urban planning and housing characteristics; in particular are analysed the unitary residential values of buildings located in the Ligurian and Tuscan coasts, served by major public transport services and located in the immediate vicinity of port facilities for recreational medium-large boating (with more than 50 moorings).

The survey conducted shows that the values range from a minimum of $3980 € / \mathrm{sqm}$ to a maximum of $5850 € / \mathrm{sqm}$.

\footnotetext{
${ }^{7}$ Estimated at $7 \%$ of the construction cost.

${ }^{8}$ Estimated at $2 \%$ of the real estate value.

${ }^{9}$ Estimated at $3 \%$ of the construction cost.

${ }^{10}$ Estimated at $10 \%$ of the construction cost.

${ }^{11}$ As indicated in the tender documents, the price will fluctuate between 25 and 30 million euros (values are not binding for the municipality); the value taken in the CRA amounted to $€ 27.5$ million euros.
} 
Table 3 Unit values estimated for sale and leasing

\begin{tabular}{l|r|r}
\hline \multirow{2}{*}{ Intended use } & \multicolumn{2}{l}{ Unitary value } \\
\cline { 2 - 3 } & Min. & Max. \\
\hline \multicolumn{3}{l}{ Sale } \\
\hline Residential (€/sqm) & 3900 & 5800 \\
\hline Commercial (€/sqm) & 2000 & 4500 \\
\hline Car park (€/car park) & 45,000 & 70,000 \\
\hline Offices (€/sqm) & 2000 & 3000 \\
\hline Moorings (€/mooring) & 35,000 & 100,000 \\
\hline Lease & 204 & 290 \\
\hline Commercial (€/sqm/month) & 140 & 220 \\
\hline Hospitality (€/room/day) & 120 & 150 \\
\hline Managerial (€/sqm/year) & 4500 & 18,000 \\
\hline Moorings (€/space/year)
\end{tabular}

In the CRA, it was assumed that the values of residential properties range from a minimum of $3900 € / \mathrm{sqm}$ and a maximum of $5800 € /$ sqm. $^{12}$ With regard to other intended uses (commercial, offices, hospitality and moorings), the sales and rental values assumed were gathered by observers in the housing market or from the offers listed on major real estate deals sites ${ }^{13}$ for the Foce area ${ }^{14}$ or by the companies that manage facilities for recreational boating in the Ligurian area.

Table 3 shows the unit values assumed in the CRA model.

It is expected that the sale of the property will take place within the six years after the closure of the building site.

The evaluation of the economic sustainability of the project is developed in relation to a "sale and management" real estate scenario that considers five years for the construction of buildings (residences, offices, shops and hotel) and subsequent six years for sale; the Sports Hall (Pavilion S) and part of parking located in Piazzale Kennedy are considered in management concession-to the Private Investor by the Municipality of Genoa-for fifty years. At the end of the concession (the 56th year), they will go back to being fully owned by the Municipality of Genoa.

\section{Results}

The analysis of the indicator values (NPV and IRR) obtained by the CRA models highlights limit conditions of economic and financial sustainability (Table 4). For

\footnotetext{
${ }^{12}$ The variability takes into account the different locations of the properties inside the buildings (floor level, view, brightness, etc.).

${ }^{13}$ Casa.it; Immobiliare.it.

${ }^{14}$ Genoa District where the intervention is located.
} 
Table 4 Scenarios and financial sustainability indicators (NPV and IRR)

\begin{tabular}{|c|c|c|c|c|c|}
\hline Scenario & $\begin{array}{l}\text { Waterway } \\
\text { cost }\end{array}$ & Planning fees & $\begin{array}{l}\text { Quantity } \\
\text { (sqm) }\end{array}$ & $\begin{array}{l}\text { NPV (million } \\
€)\end{array}$ & $\operatorname{IRR}(\%)$ \\
\hline $\begin{array}{l}\text { Sale and } \\
\text { management }\end{array}$ & $100 \% \mathrm{PI}$ & $\begin{array}{l}\text { YES } \\
(20 \text { million } €)\end{array}$ & $\begin{array}{l}\text { Residential: } \\
15,000 \\
\text { Tertiary: } \\
24,000 \\
\text { Commercial: } \\
7000 \\
\text { Expo } 7000\end{array}$ & 21.2 & 3.8 \\
\hline \multicolumn{6}{|c|}{ Alternative scenarios } \\
\hline 1 & $\begin{array}{l}50 \% \mathrm{M} \\
50 \% \mathrm{PI}\end{array}$ & NO & $\begin{array}{l}\text { Residential: } \\
15,000 \\
\text { Tertiary: } \\
24,000 \\
\text { Commercial: } \\
7000 \\
\text { Expo } 7000\end{array}$ & 62.5 & 6.3 \\
\hline 2 & $\begin{array}{l}50 \% \mathrm{M} \\
50 \% \mathrm{PI}\end{array}$ & NO & $\begin{array}{l}\text { Residential: } \\
29,000 \\
\text { Tertiary: } \\
10,000 \\
\text { Commercial: } \\
7000 \\
\text { Expo } 7000\end{array}$ & 88.5 & 7.5 \\
\hline 3 & $\begin{array}{l}50 \% \mathrm{M} \\
50 \% \mathrm{PI}\end{array}$ & NO & $\begin{array}{l}\text { Residential: } \\
35,000 \\
\text { Tertiary: } \\
10,000 \\
\text { Commercial: } \\
7000 \\
\text { Expo } 7000\end{array}$ & 101.7 & 8.2 \\
\hline 4 & $\begin{array}{l}50 \% \mathrm{M} \\
50 \% \mathrm{PI}\end{array}$ & NO & $\begin{array}{l}\text { Residential: } \\
40,000 \\
\text { Tertiary: } \\
10,000 \\
\text { Commercial: } \\
7000 \\
\text { Expo } 7000\end{array}$ & 111.0 & 8.6 \\
\hline 5 & $100 \% \mathrm{M}$ & $\begin{array}{l}\text { YES } \\
(20 \text { million } €)\end{array}$ & $\begin{array}{l}\text { Residential: } \\
40,000 \\
\text { Tertiary: } \\
10,000 \\
\text { Commercial: } \\
7000 \\
\text { Expo } 7000\end{array}$ & 125.1 & 10.0 \\
\hline \multicolumn{5}{|c|}{$\mathrm{M}=$ Municipality of Genoa } & \\
\hline
\end{tabular}


the "sale and management" scenario, the NPV is positive (although low) while the IRR is below the minimum acceptable limits for this type of real estate investments $(12.5 \%) .{ }^{15}$ The cost of the waterway (67.5 million euros) has the greatest negative impact on the sustainability indicators; the expected revenue relating to selling and renting moorings ${ }^{16}$ is unable to sustain the high cost. Five alternative scenarios are therefore established and configured according to a different combination of some variables such as: the planning fees to be paid to the municipality ${ }^{17}$; the allocation of the construction costs of the waterway; the amount of the areas for the intended uses (Table 4).

The economic sustainability indicators's values show that only the scenario 5 can be considered sustainable: the NPV value is equal to 125.1 million euros while the IRR is equal to $10.0 \%$, close to the minimum acceptability threshold.

This scenario was configured considering that the waterway will be constructed entirely by the municipality (and leased for 50 years), that Private Investor will pay the planning fees (estimated at $€ 20$ million) and that the distribution of the areas will be aligned with the one indicated in the previous "Blueprint" competition notice (Fig. 1-left) with 40,000 sqm of residential area. ${ }^{18}$

\section{Conclusions}

The economic and financial evaluation of the "Levante Waterfront" in Genoa point out that the configured scenario based on the indication of the tender documents is not economically sustainable for a private investor; the construction cost of the waterway connecting with the Porto Antico area is the work that has the most negative impact on the economic feasibility of the intervention.

The only scenario that is feasible, despite having an IRR value slightly below the minimum threshold, is the one that provides for the construction of the entire waterway by the Municipality of Genoa and the subsequent concession of the moorings for 50 years to the Private Investor (scenario 5); the scenario also provides for an increase in the residential area (from 15,000 to 40,000 sqm) and a decrease of the tertiary area (from 24,000 to 10,000 sqm).

\footnotetext{
${ }^{15}$ The value is determined by the sum of three components (Prizzon 1995): the profitability of an alternative low-risk investment (1.5\% - thirty-year Italian treasury bonds); inflation contingency (1\%); investment property inherent risk (10\%).

${ }^{16} \mathrm{It}$ is considered that $50 \%$ of the moorings are sold in the first six years and the remaining $50 \%$ are rented for 50 years, after which they will be sold. In the alternative 1-4 scenarios, the number of leased and sold moorings is reduced by $50 \%$ because half of the waterway is considered public property; in scenario 5, they are considered in concession for 50 years.

${ }^{17}$ Quantified by mutual agreement between the Municipality of Genoa and the Private Investor at the time of preparation of the Operative Urban Plan (PUO).

${ }^{18}$ In relation to the characteristics of the real estate market of Genoa, the residential use is the one that guarantees a higher profit margin.
} 
The results obtained, however, must be carefully evaluated in relation to some uncertainty factors which could further affect the feasibility of the intervention, including:

- the costs of disposing of the materials from the demolition, where the presence of pollutant substances may be identified (asbestos, etc.);

- the potential demand for buildings that will be constructed and their corresponding sales timing, in relation to a Genoese real estate market that has been characterised by lower prices and a lack of vibrancy in trading activity for over a decade in relation to the entire existing housing stock;

- the permitting timelines and any requirements that might affect the economic feasibility conditions.

Also, if the feasibility conditions can be guaranteed by a massive use of public resources, it is permissible to ask what the overall social benefits obtained from an operation conceived in this way are and whether they are justified compared to a "fair" allocation of public economic resources.

In other words, in another vision of sustainability understood as being fair to work, an intervention should first be true (economically feasible), good (socially correct) and beautiful (environmentally acceptable) (Sdino et al. 2018).

\section{References}

Brenner, N., \& Theodore, N. (Eds.). (2002). Spaces of neoliberalism: urban restructuring in North America and Western Europe. Malden: Blackwell.

Calabrò, F., \& Della Spina, L. D. (2014). "The public-private partnerships in buildings regeneration: A model appraisal of the benefits and for land value capture" in Advanced Materials Research. Trans Tech Publications Ltd., 931-932, 555-559.

Cutini, V., \& Rusci, S. (2016). Ai tempi della crisi. il mercato immobiliare e le influenze sulla pianificazione. Archive of Urban and Regional Studies, (116), 91-114.

De Gaspari, M. (2013). Bolle di mattone. La crisi italiana a partire dalla città. Come il mattone può distruggere un'economia. Milan: Mimesis.

Dicken, P. (2003). Global shift: reshaping the global and economic map in the 21st century. New York: Guilford Press.

Napoli, G. (2015). "Financial sustainability and morphogenesis of urban transformation project". In Lecture Notes in Computer Science (including subseries Lecture Notes in Artificial Intelligence and Lecture Notes in Bioinformatics) (Vol. 9157, pp. 178-193). Springer.

Nespolo, L. (2012). Rigenerazione urbana e recupero del plusvalore fondiario. Le esperienze di Barcellona e Monaco di Baviera. Florence: IRPET.

Ombuen, S. (2018). "Rendite e finanziarizzazione nelle economie urbane". In: Urban@it National Centre of Studies for urban policy -Fourth Report on the cities. Il governo debole delle economie urbane. Bologna: Il Mulino.

Palermo, P., \& Ponzini, D. (2012). At the crossroads between urban planning and urban design: Critical lessons from three Italian case studies. Planning Theory \& Practice, 13(3), 445-460.

Prizzon, F. (1995). La valutazione degli investimenti immobiliari. Turin: Celid.

Rebaudengo, M., \& Prizzon, F. (2017). "Assessing the investments sustainability after the new code on public contracts". In Lecture Notes in Computer Science (including subseries Lecture Notes in Artificial Intelligence and Lecture Notes in Bioinformatics) (Vol. 10409, pp. 473-484). LNCS. 
Sassen, S. (2001). The global city. New York: London, Tokio, Princeton University Press, Princeton. Sassen, S. (2018). Cities in a world economy. New York: Sage.

Sdino, L., Rosasco, P., \& Magoni, S. (2016). "The financial feasibility of a real estate project: the case of the Ex Tessitoria Schiatti”. In F. Calabrò, L. D. Della Spina (Eds.), Procedia Social and Behavioral Sciences (Vol. 223, pp. 217-224).

Sdino, L., Rosasco, P., \& Magoni, S. (2018). True, fair and beautiful: Evaluative paradigms between the encyclical letter laudato Sì and Keynes (pp. 87-98). Green Energy and Technology: Springer.

Open Access This chapter is licensed under the terms of the Creative Commons Attribution 4.0 International License (http://creativecommons.org/licenses/by/4.0/), which permits use, sharing, adaptation, distribution and reproduction in any medium or format, as long as you give appropriate credit to the original author(s) and the source, provide a link to the Creative Commons license and indicate if changes were made.

The images or other third party material in this chapter are included in the chapter's Creative Commons license, unless indicated otherwise in a credit line to the material. If material is not included in the chapter's Creative Commons license and your intended use is not permitted by statutory regulation or exceeds the permitted use, you will need to obtain permission directly from the copyright holder. 